\title{
МОРФОФУНКЦІОНАЛЬНІ ЗМІНИ ЯЄЧНИКІВ ЩУРІВ ПІД ВПЛИВОМ АЦЕТАТУ СВИНЦЮ В ЕКСПЕРИМЕНТІ
}

Вступ. Свинець є природним токсичним металом, який міститься в земній корі. Як токсикант він перебуває в центрі уваги не лише екологів, токсикологів і гігієністів, а й морфологів та клініцистів. Це зумовлено тим, що отруєння сполуками свинцю супроводжуються порушенням фрункціонування нервової, серцево-судинної, травної, сечовидільної та репродуктивної систем.

Мета дослідження - вивчити вплив малих, середніх і великих доз ацетату свинцю на біохімічні показники та морфологічний стан яєчників щурів в експерименті.

Методи дослідження. Дослідження виконано на 40 статевозрілих нелінійних щурах-самицях, розділених на 4 експериментальні групи, яким упродовж 30 днів давали для пиття розчин ацетату свинцю 3 розрахунку 0,05, 10 та 60 мг/кг маси тварини. У роботі використано біохімічні, гістологічні й статистичний методи дослідження.

Результати й обговорення. Встановлено, що у 3-й групі тварин, порівняно з 2-ю, концентрація дієнових кон'югатів (ДК) була вищою у 2,8 раза, ТБК-активних продуктів (ТБК-ап) - у 2,1 раза. У 4-й групі щурів, порівняно з 2-ю, вміст ДК був більшим у 4,3 раза, ТБК-ап - у 2,7 раза. У 4-й групі тварин, порівняно з 3-ю, рівень ДК був вищим на 55,8 \%, ТБК-ап - на 24,8 \%. У 3-й групі щурів, порівняно з 2-ю, супероксиддисмутазна (СОД) активність була меншою на 34,7 \%, а каталазна (КАТ) - більшою на 32,3 \%. У 4-й групі тварин, порівняно з 2-ю, СОД активність була нижчою на 63 \%, а КАТ активність - на 86,6 \%. У 4-й групі щурів, порівняно з 3-ю, СОД активність була меншою на 43,3 \%, а КАТ активність - на 89,9 \%. Результати проведених морфологічних досліджень яєчників у тварин усіх груп показали, що з наростанням дози ацетату свинцю поглиблювалися морфоологічні зміни як у кірковій, так і у мозковій речовинах яєчників щурів. Це призводило до зміни товщини поверхневих структур яєчників та зменшення кількості фролікулів, що свідчило про порушення процесів їх росту і дозрівання.

Висновок. При впливі малих доз ацетату свинцю зміни мають адаптаційно-компенсаторний характер, а при дії великих - дистрофрічно-деструктивний.

КЛЮчОВІ СЛОВА: яєчники; щури-самиці; свинець; інтоксикація; морфологічні зміни; біохімічні зміни крові.

ВСТУП. Свинець є природним токсичним металом, який міститься в земній корі. Його широке використання призвело до значного забруднення навколишнього середовища, впливу на людину та значних проблем зі здоров'ям у багатьох частинах світу [1-3].

За даними ВОО3, свинець є одним із найбільш глобальних і небезпечних хімічних елементів, оскільки цей метал має достатньо широку сореру застосування в різних галузях господарства та побуті, а також великі обсяги виробництва і світової торгівлі, що зумовлює закономірне надходження свинцю в об'єкти довкілля, де він поширюється на значні відстані від джерел забруднення [4-6]. Всесвітня організація охорони

(с) Я. О. Білик, С. В. Чорній, О.В.Денефріль, Л. Я. Федонюк, Н. Ю. Терлецька, 2021. здоров'я визначила свинець як одну з 10 хімічних речовин, які викликають серйозне занепокоєння для громадського здоров'я, що потребує заходів з боку держав-членів для захисту здоров'я працівників, дітей і жінок репродуктивного віку.

Унаслідок забруднення навколишнього середовища міграція свинцю в системі "вода ґрунт - атмоссрера - харчові продукти - людина" набула значних розмірів. Згідно з висновком комітету ООН 3 охорони навколишнього середовища, свинець визнано одним із глобальних забруднювачів, що потребують першочергового контролю.

Свинець як токсикант перебуває в центрі уваги не лише екологів, токсикологів і гігієністів, а й морфологів та клініцистів, які представляють 
різні галузі медицини і біології. Це зумовлено тим, що за порівняно короткий період вміст даної потенційно токсичної хімічної речовини у навколишньому середовищі збільшився в десятки й навіть сотні разів, і, що важливо, це набуло глобального характеру [7, 8].

Свинець має виражені мембранотоксичні властивості, змінює активність ензимів і перебіг біохімічних процесів, здатний до матеріальної та фрункціональної кумуляції і при тривалій експозиції спричиняє віддалені негативні біоефекти. Отруєння сполуками свинцю супроводжуються порушенням фрункціонування нервової, серцево-судинної, травної систем, ураженням кровотворної та сечовидільної систем $[9,10]$. Особливий інтерес викликає вплив свинцю на репродуктивну систему [11-14], який призводить до різних порушень у розвитку плода, що підтверджено експериментальними та клінічними дослідженнями. Тому вивчення структурних і фрункціональних аспектів свинцевої інтоксикації $€$ актуальним завданням.

Мета дослідження - вивчити вплив малих, середніх і великих доз ацетату свинцю на біохімічні показники та морфологічний стан яєчників щурів в експерименті.

МЕТОДИ ДОСЛІДЖЕННЯ. РоботУ виконано на базі Центральної науково-дослідної лабораторії Тернопільського національного медичного університету імені І. Я. Горбачевського МO3 України.

Дослідження проведено на 40 нелінійних щурах-самицях масою 180-210 г віком 95110 днів, розділених на 4 експериментальні групи: 1-ша - контроль (K); 2-га - щури, яким упродовж 30 днів давали для пиття розчин ацетату свинцю з розрахунку 0,05 мг/кг маси тварини; 3-тя - щури, яким протягом 30 днів давали для пиття розчин ацетату свинцю з розрахунку 10 мг/кг маси тварини; 4-та - щури, яким упродовж 30 днів давали для пиття розчин ацетату свинцю з розрахунку 60 мг/кг маси тварини.

Утримували щурів та проводили експерименти на них відповідно до положень Європейської конвенції про захист хребетних тварин, що використовуються для дослідних та інших наукових цілей [15]. Усі експерименти проводили в першій половині дня в спеціально відведеному приміщенні при температурі $18-22^{\circ} \mathrm{C}$, відносній вологості 40-60 \% і освітленості 250 лк.

За допомогою біохімічних методів дослідження у крові тварин визначали концентрацію дієнових кон'югатів (ДК), ТБК-активних продуктів (ТБК-ап), супероксиддисмутазну (СОД) і каталазну (КАТ) активність [16-18].

Забір матеріалу для світлооптичного дослідження проводили за загальноприйнятою методикою $[19,20]$. Відразу ж після видалення яєчника його зважували і вирізали із середньої частини органа шматочки для мікроскопічного дослідження. Матеріал фріксували протягом 2-3 тижнів у $10 \%$ розчині нейтрального фрормаліну з триразовою зміною фріксатора, потім зневоднювали в спиртах зростаючої концентрації, після чого заливали у парафрінові блоки. Мікротомні зрізи товщиною 5 мкм забарвлювали гематоксилін-еозином. Мікроскопічне дослідження препаратів проводили з використанням світлового мікроскопа "Nicon Eclipse Ci" (виробництво Японії), об'єктивів ×4, 10, 20 та окуляра $\times 10$. Фотограсрували гістологічні препарати камерою "Sigeta" (виробництво Японії). Це дало можливість вивчити структуру яєчника щура в нормі, а також характер і глибину морфологічних змін, послідовність розвитку дистрофрічних та деструктивних процесів під впливом ацетату свинцю.

Статистичну обробку циоррових даних здійснювали за допомогою програмного забезпечення Excel ("Microsoft", США) і STATISTICA 7.0 ("Statsoft", США) з використанням параметричних та непараметричних методів оцінки отриманих даних. Для всіх показників розраховували значення середньої арифметичної вибірки (М), ії̈ дисперсії і помилки середньої (m). Достовірність різниці значень між незалежними кількісними величинами встановлювали при нормальному розподілі за критерієм Манна - Уїтні.

РЕЗУЛЬТАТИ Й ОБГОВОРЕННЯ. ПрИ аНалізі показників пероксидного окиснення ліпідів (табл. 1) у тварин 2-ї групи, яким давали мало-

Таблиця 1 - Зміни показників пероксидного окиснення ліпідів у сироватці крові тварин

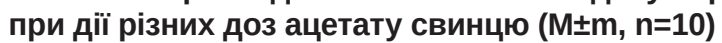

\begin{tabular}{|c|c|c|c|}
\hline \multirow{2}{*}{$\begin{array}{c}\text { Група } \\
\text { тварин }\end{array}$} & \multirow{2}{*}{ Умова експерименту } & \multicolumn{2}{|c|}{ Показник } \\
\hline & & ДК, ум. од./мл & ТБК-ап, мкмоль/л \\
\hline 1-ша & Контроль & $0,84 \pm 0,03$ & $2,50 \pm 0,04$ \\
\hline 2-га & Ацетат свинцю (0,05 мг/кг) & $1,23 \pm 0,07^{*}$ & $3,42 \pm 0,06^{*}$ \\
\hline 3-тя & Ацетат свинцю (10 мг/кг) & $3,42 \pm 0,16^{\star, \star \star}$ & $7,34 \pm 0,57^{\star, \star \star}$ \\
\hline 4-та & Ацетат свинцю (60 мг/кг) & $5,33 \pm 0,22^{\star, \star \star, \#}$ & $9,16 \pm 0,43^{\star, \star *, \#}$ \\
\hline
\end{tabular}

Примітка. Тут і в таблиці 2: * - показники достовірні порівняно 3 контролем; ** - показники достовірні порівняно 3 2-ю групою; * - показники достовірні порівняно з 3-ю групою. 
дозові рівні свинцю, що не перевищували загальнотоксичної дії, виявлено зростання концентрації ДК на 46,4% (p<0,001) порівняно з тваринами контрольної групи, а ТБК-ап - на 36,8 \% ( $p<0,001)$ відповідно.

У щурів 3-ї групи, яким давали середні дози свинцю, виявлено зростання концентрації ДК у 4,7 раза $(p<0,001)$ порівняно з показниками тварин контрольної групи, а ТБК-ап - у 2,9 раза (р<0,001) відповідно (див. табл. 1).

У щурів 4-ї групи, яким давали великі дози свинцю, що викликають інтоксикацію в організмі, спостерігали збільшення вмісту ДК у 6,3 раза ( $<<0,001)$ порівняно 3 тваринами контрольної групи, а ТБК-ап - у 3,7 раза ( $p<0,001)$ відповідно (див. табл. 1).

При порівнянні ступеня токсичного впливу свинцю на процеси пероксидного окиснення ліпідів виявлено, що у 3-й групі щурів, порівняно з 2-ю, рівень ДК був вищим у 2,8 раза ( $<<0,001)$, ТБК-ап - у 2,1 раза (p<0,001). У 4-й групі тварин, порівняно з 2-ю, концентрація ДК була більшою в 4,3 раза $(p<0,001)$, ТБК-ап - у 2,7 раза ( $<<0,001)$. У 4-й групі щурів, порівняно 3 3-ю, вміст ДК був вищим на 55,8 \% ( $p<0,001)$, ТБК-ап - на $24,8 \%(p<0,001)$.

У результаті проведених досліджень встановлено (табл. 2), що у сироватці крові щурів 2-ї групи, яким давали малодозові рівні свинцю, що не перевищували загальнотоксичної дії, виявлено зростання СОД активності на $54 \%$ ( $<<0,001)$ порівняно 3 тваринами контрольної групи, а показник КАТ активності збільшився у 2,5 раза.

У щурів 3-ї групи, яким давали середні дози свинцю, не виявлено зростання СОД активності порівняно з тваринами контрольної групи, але КАТ активність підвищилась у 3,4 раза ( $p<0,001)$ (див. табл. 2).

У щурів 4-ї групи, яким давали великі дози свинцю, що викликають інтоксикацію в організмі, спостерігали зниження СОД активності на $43 \%$ ( $<<0,001)$ порівняно 3 тваринами контрольної групи, а КАТ активності - на 66,3 \% (р<0,001) відповідно (див. табл. 2).

При порівнянні ступеня токсичного впливу свинцю на антиоксидантну активність щурів виявлено, що у 3-й групі тварин, порівняно з 2-ю, СОД активність була меншою на $34,7 \%$ ( $<<0,001)$, а КАТ активність - більшою на 32,3\% (p<0,001). У 4-й групі щурів, порівняно з 2-ю, СОД активність була нижчою на $63 \%$ ( $<<0,001)$, а КАТ активність - на 86,6 \% (p<0,001). У 4-й групі тварин, порівняно з 3-ю, СОД активність була меншою на 43,3 \% ( $<<0,001)$, а КАТ активність на $89,9 \%(p<0,001)$.

Отже, ацетат свинцю викликає активацію антиоксидантів тільки в малих дозах. Середні дози зумовлюють активацію лише каталазної активності, а великі - спричиняють пригнічення активності антиоксидантів.

Проведені морфологічні дослідження яєчників тварин контрольної групи показали, що орган покритий переважно одношаровим кубічним епітелієм, проте траплялись ділянки призматичного та плоского епітелію, на апікальній поверхні якого візуалізуються мікроворсинки.

Як свідчать результати світлооптичної мікроскопії яєчників тварин контрольної групи, під епітелієм розташована білкова оболонка, що складається переважно з колагенових та еластичних волокон, а також невеликої кількості гладких міоцитів. У складі органа чітко візуалізуються зовнішня кіркова та внутрішня мозкова речовини. Кіркова речовина утворена сполучною тканиною, що містить колагенові та незначну кількість еластичних волокон, а також велику кількість фролікулів різного ступеня зрілості (примордіальні, первинні, вторинні, третинні фолікули), жовті тіла і кровоносні судини. Мозкова речовина яєчників щурів контрольної групи представлена сполучнотканинною стромою, що містить велику кількість еластичних волокон, багато кровоносних судин, нервові волокна та нервові закінчення.

При гістологічному дослідженні яєчників щурів 2-ї групи встановлено, що структурна організація органа піддослідних тварин практично не відрізняється від такої в контрольній групі. У цей термін експерименту в кірковій та мозковій речовинах яєчників спостерігають густу сітку колагенових волокон у складі білкової оболонки.

Таблиця 2 - Зміни ензимів антиоксидантної системи у сироватці крові тварин при дії різних доз ацетату свинцю (M $\pm m, n=10)$

\begin{tabular}{|c|c|c|c|}
\hline \multirow[b]{2}{*}{$\begin{array}{l}\text { Група } \\
\text { тварин }\end{array}$} & \multirow[b]{2}{*}{ Умова експерименту } & \multicolumn{2}{|c|}{ Показник } \\
\hline & & $\begin{array}{c}\text { СОД активність, } \\
\text { ум. од./мл }\end{array}$ & $\begin{array}{c}\text { КАТ активність, } \\
\text { мкат/л }\end{array}$ \\
\hline 1-ша & Контроль & $3,72 \pm 0,03$ & $0,92 \pm 0,04$ \\
\hline 2-га & Ацетат свинцю (0,05 мг/кг) & $5,73 \pm 0,09^{\star}$ & $2,32 \pm 0,08^{*}$ \\
\hline 3-тя & Ацетат свинцю (10 мг/кг) & $3,74 \pm 0,12^{\star \star}$ & $3,07 \pm 0,35^{*}$ \\
\hline 4-та & Ацетат свинцю (60 мг/кг) & $2,12 \pm 0,17^{*, * *, \#}$ & $0,31 \pm 0,06^{*, * \star, \#}$ \\
\hline
\end{tabular}


За допомогою світлової мікроскопії виявляють поодинокі примордіальні фолікули, що містять овоцит, оточений одним шаром плоских епітеліальних клітин. Первинні фролікули оточені одношаровим кубічним епітелієм. Вторинні фолікули мають добре виражену прозору оболонку, овоцит оточений багатошаровим епітелієм кубічної фрорми. Також характерною ознакою вторинних фолікулів $€$ поява тека-шару навколо нього, що забезпечує окреме кровопостачання фолікула.

Також добре візуалізуються третинні фролікули, для яких характерним $€$ формування порожнини у товщі фолікулярних клітин, що заповнена фоолікулярною рідиною. Зрілий (передовуляційний) сролікул має повністю сформовану порожнину 3 фолікулярною рідиною, в якій вільно плаває яйцеклітина (рис. 1).

Проте виявлено, що у кірковій речовині яєчників щурів 2-ї групи збільшується відносна площа, яку займають жовті тіла, порівняно 3 тваринами контрольної групи. У всіх щурів жовті тіла зовні вкриті сполучнотканинною капсулою, мають округлу форму. В товщі жовтого тіла візуалізуються сполучнотканинні прошарки, в яких розміщені кровоносні та лімфатичні судини. Основу жовтого тіла становлять лютеоцити клітини неправильної форми з базофрільно забарвленими ядрами по центру клітини та еозинофрільною цитоплазмою, що свідчить про активний стероїдогенез. Лютеоцити відрізняються за розмірами залежно від розташування у жовтому тілі - по перисрерії переважають дрібні клітини зірчастої фрорми з великим овальним ядром.

При гістологічному дослідженні яєчників тварин 3-ї групи спостерігали порушення структурних компонентів кіркової та мозкової речовин, перш за все кровоносних судин. В яєчниках щурів, яким давали середні дози ацетату свинцю, встановлено помірно збільшене кровонаповнення кіркової та мозкової речовин (рис. 2).

При світловій мікроскопії виявлено нерівномірне кровонаповнення судин із помірним периваскулярним набряком, що свідчило про збільшення проникності судин.

Аналіз стану фолікулів у складі кіркової речовини яєчників показав, що у щурів 2-ї групи, порівняно $з$ контрольною, незначно зросла кількість примордіальних фролікулів у неовулюючих яєчниках, збільшилась товщина білкової оболонки, незначно знизилась кількість атретичних фролікулів.

Ініціювання росту фолікулів $€$ незворотним процесом, унаслідок чого поступово відбувається репродуктивне старіння. Однак саме поступова активація примордіальних фролікулів забез- печує баланс між постійним рекрутуванням фолікулів до естрального циклу та одночасним обмеженням передчасного виснаження оваріального резерву.

Проведені морсоологічні дослідження яєчників тварин 3-ї групи, яким давали великі дози ацетату свинцю, показали, що, порівняно з контрольною групою, макроскопічно відзначено зменшення яєчників у розмірах, їх гіперемію, зменшення товщини поверхневого епітелію і товщини білкової оболонки.

При світлооптичному дослідженні яєчників щурів 3-ї групи встановлено, що в складі кіркової речовини зменшується кількість фролікулів на всіх стадіях їх розвитку та дозрівання: практично відсутні як первинні, так і вторинні та третинні фролікули, є невелика кількість примор-

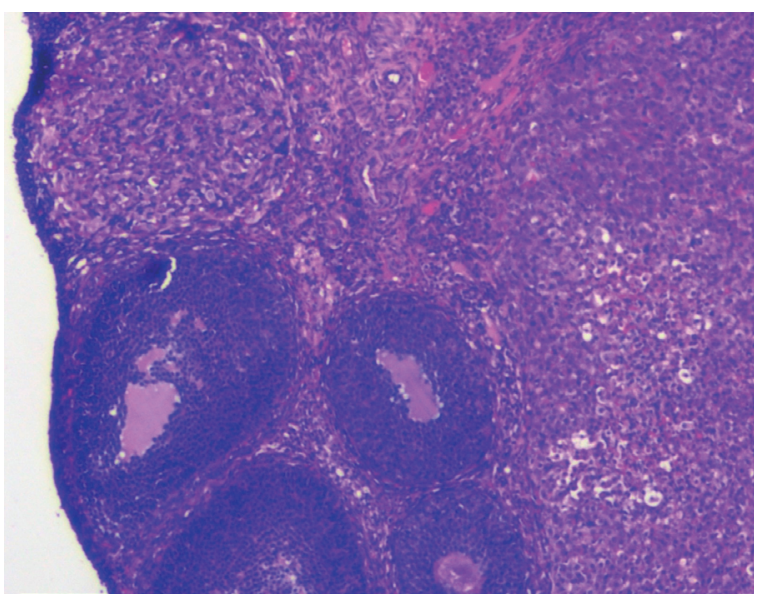

Рис. 1. Структурна організація яєчника тварини при впливі малих доз ацетату свинцю. Фолікули різного ступеня розвитку в кірковій речовині органа. Кровоносні судини, еластичні та колагенові волокна в складі сполучнотканинної строми мозкової речовини. Забарвлення гематоксилінеозином. $\times 100$.

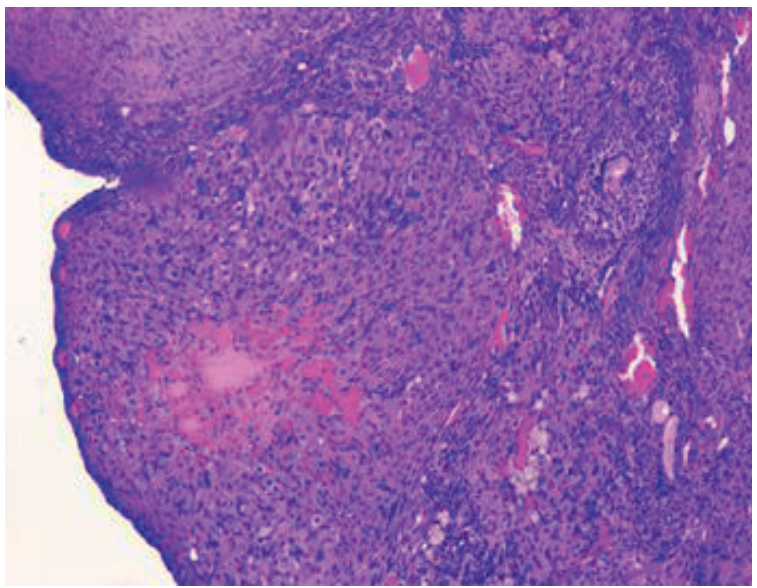

Рис. 2. Гістологічне дослідження яєчника тварини при впливі середніх доз ацетату свинцю. Кровонаповнені судини в складі кіркової та мозкової речовин. Забарвлення гематоксилін-еозином. ×100. 
діальних фролікулів, які розташовані на периферії кіркової речовини яєчника, і поодинокі жовті тіла, що хаотично локалізуються в паренхімі органа.

Отже, 3 наростанням дози ацетату свинцю поглиблюються морфологічні зміни як у кірковій, так і у мозковій речовинах яєчників щурів, що призводить до зміни товщини поверхневих структур яєчників та зменшення кількості фролікулів, це свідчить про порушення процесів їх росту і дозрівання.

ВИСНОВКИ. 1. Ацетат свинцю викликає активацію пероксидного окиснення ліпідів і протеїнів в організмі щурів-самиць, що прямо залежить від дози свинцю.

\section{СПИСОК ЛІТЕРАТУРИ}

1. Слободян С. О. Стан антиоксидантної системи організму щурів в умовах тривалого кадмієвого і свинцевого навантаження / С. О. Слободян, Б. В. Гутий // Вісн. Полтав. держ. аграр. акад. - 2020. - № 1. С. $196-201$.

2. Смоляр В. Т. Свинець в харчових продуктах і раціонах / В. І. Смоляр, Г. І. Петрашенко // Проблеми харчування. - 2017. - № 4. - С. 42-51.

3. Lead: Tiny but mighty poison / C. Sachdeva, K. Thakur, A. Sharma, K. Sharma // Indian Journal of Clinical Biochemistry. - 2018. - 33 (2). - P. 132-146. - Access mode : https://doi.org/10.1007/s12291-017-0680-3.

4. Ткачишин В. С. Інтоксикації свинцем і його неорганічними сполуками / В. С. Ткачишин // Scientific Review. - 2021. - 17, № 4. - C. 6-11.

5. Impact of environmental toxin exposure on male fertility potential / C. Krzastek, J. Farhi, M. Gray, P. Smith // Translational Andrology and Urology. - 2020. - 9 (6). P. 2797-2813. -Access mode : https://doi.org/ 10.21037/ tau-20-685.

6. Майор В. В. Дослідження впливу комплексу важких металів (свинцю, заліза, золота, срібла) на стан репродуктивної системи / В. В. Майор, І. І. Колосова, В. Ф. Шаторна // Вісн. Вінниц. нац. мед. ун-ту. 2016. - № 2. - C. 341-344.

7. Білецька Е. М. Комбінована дія низькодозових рівнів свинцю та цинку на кісткову тканину щурів / Е. М. Білецька, Н. М. Онул, В. В. Калінічева // Запоріз. мед. журн. - 2018. - 20, № 1. - С. 101-104.

8. Островська С. С. Ультраструктура міокарда лівого шлуночка щурів після поєднаної дії радіації та важких металів / С. С. Островська, В. Ф. Шаторна, О. А. Земляний // Зб. матеріалів доп. учасників наук.-практ. конф. - Тернопіль, 2019. - С. 92-93.

9. Зміни кардіогенезу під впливом важких металів та за умов корекції в експерименті у щурів / В. Ф. Шаторна, О. О. Нефьодова, О. О. Нефьодов [та ін.] // Світ медицини та біології. - 2020. - 74, № 4. - С. 219-223.

10. Asad A. Effect of lead acetate on basement membrane of seminiferous tubules of adult rat testis and protective effects of Ficus Carica: A histological study /
2. Свинець у малих дозах не викликає розвитку ендогенної інтоксикації. Ацетат свинцю спричиняє розвиток ендогенної інтоксикації в організмі тварин тільки у великих дозах: зростають утворення токсичних сполук, апоптоз клітин, зменшується екскреторна функція нирок, що пов'язано з поліорганними порушеннями.

3. У результаті дії ацетату свинцю відмічено морфологічні зміни яєчників, що наростали зі збільшенням його дози. Відзначено дозозалежне зменшення масометричних показників, кількості фролікулів та зміни товщини поверхневих структур яєчника, що найбільш виражено при використанні ацетату свинцю в дозі $60 \mathrm{Mг} / \mathrm{\kappa}$.

A. Asad, S. Hamid, K. Qama // Journal of College Physicians Surgeons Pakistan. - 2018. - 28, No. 10. P. 731-734.

11. Колосова І. І. Морфологічна характеристика яєчників щурів на різних термінах вагітності в нормі та за умов свинцевої інтоксикації / I. І. Колосова // Вісн. проблем біології і медицини. - 2016. - 1, № 126. C. 281- 287.

12. Вплив свинцю на репродуктивне здоров'я чоловіків / С. С.Островська, В. Ф. Шаторна, О. Г. Слесаренко [та ін.] // Укр. журн. медицини, біології та спорту. - 2021. - 6, № 4. - С. 16-21.

13. Counteracting effects of heavy metals and antioxidants on male fertility/ S. Ghafouri-Fard, H. Shoorei, M. Mohaqiq [et al.] // Biometals. - 2021. - 34. - P. 439491. Access mode : https://doi.org/10.1007/s10534-02100297-x(0123456789().,-volV)( 01234567.

14. Heavy metals, biomarkers of oxidative stress and changes in sperm function: A case-control study / A. C. Nsonwu-Anyanwu, E. R. Ekong, S. J. Offor [et al.] // International Journal of Reproductive BioMedicine. 2019. - 17, No. 3. - P. 163-174.

15. Gross D. Ethics in animal-based research / D. Gross, R. H. Tolba // Eur. Surg. Res. - 2015. No. 55 (1-2). - P. 43-57.

16. Коробейникова Э. Н. Модифиикация определения продуктов ПОЛ в реакции с тиобарбитуровой кислотой / Э. Н. Коробейникова // Лаб. дело. - 1989. № 7. - С. 8-10.

17. Мещишен І. Ф. Метод визначення окислювальної модифрікації білків плазми крові / І. Ф. Мещишен // Буковин. мед. вісн. - 1998. - № 1. - С. 156-158.

18. Чевари С. Роль супероксиддисмутазы в окислительных процессах клетки и метод определения ее в биологических материалах / С. Чевари, И. Чаба, Й. Сокей // Лаб. дело. - 1985. - № 11. - С. 678-681.

19. Автандилов Г. Г. Введение в количественную патологическую морфологию / Г. Г. Автандилов. - М. : Медицина, 1980. - 216 с.

20. Автандилов Г. Г. Медицинская морфометрия / Г. Г. Автандилов. - М. : Медицина, 1990. - 384 с. 


\section{REFERENCES}

1. Slobjdian, S.O., \& Gutyj, B.V. (2020). The state of antioxidant system of rats' organism under continuous cadmium and lead load. Bulletin of Poltava State Agrarian Academy, 1, 196-201. DOI: 10.31210/visnyk2020.01.24 [in Ukrainian].

2. Smolyar, V.T., \& Petrashenko, G.I. (2017). Lead in food and rations. Probl. Nutr., 4, 42-51 [in Ukrainian].

3. Sachdeva, C., Thakur, K., Sharma, A., \& Sharma, K. (2018). Lead: tiny but mighty poison. Indian J. Clin. Biochem., 33 (2), 132-146. DOI: 10.1007/s12291017-0680-3.

4. Tkachyshyn, V.S. (2021). Lead intoxication and its inorganic compounds. Sci. Rev., 17 (4), 6-11 [in Ukrainian].

5. Krzastek, C., Farhi, J., Gray, M., \& Smith, P. (2020). Impact of environmental toxin exposure on male fertility potential. Transl. Androl. Urol., 9 (6), 2797-2813. DOI: 10.21037/tau-20-685.

6. Maior, V.V., Kolosova, I.I., \& Shatorna, V.F. (2016). Investigation of the heavy metals complex (lead, iron, gold, silver) effect on the reproductive system condition. Reports of Vinnytsia National Medical University, 2, 341344 [in Ukrainian].

7. Biletska, E.M., Onul, N.M., \& Kalinicheva, V.V. (2018). Combined effect of low dose levels of lead and zinc on bone tissue of rats. Zaporozhie Med. J., 20 (1), 101-104 [in Ukrainian].

8. Ostrovskaya, S.S., Shatorna, V.F., \& Zemlyany, O.A. (2019). Ultrastructure of the left ventricular myocardium of rats after the combined action of radiation and heavy metals. Coll. Materials of Reports of Participants of Scientific-practical. Conf. Ternopil. pp. 92-93 [in Ukrainian].

9. Shatornaya, V.F., Nefyodova, O.O., Nefyodov, O.O., Kolosova, I.I., Major, V.V., Kuznetsova, O.V., ..., \& Yeroshenko, G.A. (2020). Cardiogenesis changes after the plumbic acetate impact in rats under the correction conditions in the experiment. World of Medicine and Biology, 4 (74), 219-223. DOI: 10.26724/2079-83342020-4-74-219-223. [in Ukrainian].

10. Asad, A., Hamid, S., \& Qama K. (2018). Effect of lead acetate on basement membrane of seminiferous tubules of adult rat testis and protective effects of ficus carica: a histological study. J. Colle Physicians Surg. Pak., 28 (10), 731-734.

11. Kolosova, I.I. (2016). Morphological characteristics of rat ovaries at different stages of pregnancy in normal and in condition of lead intoxication. Bull. Probl. Biol. Med., 1 (126), 281-287 [in Ukrainian].

12. Ostrovska, S.S., Shatorna, V.F., Slesarenko, O.G., Gerasymchuk, P.G., Topka, E.G., Alekseenko, Z.K., ..., \& Kosse, V.A. (2021). Impact of lead on reproductive health of men. Ukr. J. Med. Biol. Sport., 6 (4), 16-21 [in Ukrainian].

13. Ghafouri-Fard, S., Shoorei, H., Mohaqiq, M., Tahmasebi, M., Seify, M., \& Taheri, M. (2021). Counteracting effects of heavy metals and antioxidants on male fertility. Biometals, 34, 439-491. DOI: 10.1007/ s10534-021-00297-x.

14. Chinyere Nsonwu-Anyanwu, A., Raymond Ekong, E., Jeremiah Offor, S., Francis Awusha, O., Chukwuma Orji, O., Idiongo Umoh, E., ..., \& Adanna Opara Usoro, C. (2019). Heavy metals, biomarkers of oxidative stress and changes in sperm function: a casecontrol study. Int. J. Reprod. BioMed., 17 (3), 163-174. DOI: 10.18502/ijrm.v17i3.4515.

15. Gross, D., \& Tolba, R.H. (2015). Ethics in animalbased research. Eur. Surg. Res., 55 (1-2), 43-57. DOI: 10.1159/000377721.

16. Korobeynikova, E.N. (1989). Modification of the determination of POL products in the reaction with thiobarbituric acid. Lab. Work, 7, 8-10.

17. Mechyshchen, I.F. (1998). Method for determination of oxidative modification of blood plasma proteins. Bukovynian Medical Herald, 1, 156-158 [in Ukrainian].

18. Chevari, S., Chaba, I., \& Sokei, Y. (1985). The role of superoxide dismutase in the oxidative processes of the cell and a method for its determination in biological materials. Lab. Work, 11, 678-681 [in Russian].

19. Avtandilov, G.G. (1980). Introduction to quantitative pathological morphology. Moscow: Meditsina [in Russian].

20. Avtandilov, G.G. (1990). Medical morphometry. Moscow: Meditsina [in Russian].

Ya. O. Bilyk, S. V. Chorniy, O. V. Denefil, L. Ya. Fedoniuk, N. Yu. Terletska I. HORBACHEVSKY TERNOPIL NATIONAL MEDICAL UNIVERSITY

\section{MORPHO-FUNCTIONAL CHANGES OF RATS' OVARY UNDER THE INFLUENCE OF LEAD ACETATE IN THE EXPERIMENT}

\section{Summary}

Introduction. Lead is a natural toxic metal found in the earth's crust. As a toxicant it is in the focus of attention not only of ecologists, toxicologists and hygienists, but also morphologists and clinicians. This is due to the fact that poisoning by lead compounds is accompanied by dysfunction of the nervous, cardiovascular, digestive, urinary and reproductive systems. 
The aim of the study - to learn the effect of low, medium and high doses of lead acetate on biochemical parameters and morphological status of rats' ovaries in the experiment.

Materials and Methods. The study was performed on 40 nonlinear female rats, divided into 4 experimental groups. Rats were given 30 days to drink a solution of lead acetate at a rate of $0.05 \mathrm{mg} / \mathrm{kg}, 10 \mathrm{mg} / \mathrm{kg}$ and $60 \mathrm{mg} / \mathrm{kg}$ of animal weight. Biochemical, histological and statistic metods were used in the work.

Results and Discussion. It was found that in group III of animals, compared with II, DC were 2.8 times higher, TBA-active products were observed more than 2.1 times. In group IV of animals in comparison with group II, DCS were 4.3 times higher, TB-active products were detected 2.7 times more. In group IV of animals in comparison with group III of animals, DCs were higher by $55.8 \%$, TB-active products were found by $24.8 \%$. It was found that in group III of animals, compared with II, SOD was lower by $34.7 \%$, and catalase activity was higher by $32.3 \%$. In group IV of animals, compared with group II, SOD was lower by $63 \%$, catalase activity - by $86.6 \%$. In group IV animals, compared with group III, SOD was lower by $43.3 \%$ and catalase activity - by $89.9 \%$. As the dose of lead acetate increases, morphological changes in both cortex and medulla of rats' ovaries deepen, which leads to changes in the thickness of ovarian surface structures and a decrease in the number of follicles, indicating impaired growth and maturation.

Conclussions. Under the influence of small doses of lead acetate changes have adaptive character, and under the large doses - degenerative.

KEY WORDS: ovary; female rats; lead; intoxication; morphological changes; biochemical changes in blood.

Отримано 23.11.21

Адреса для листування: Л. Я. Федонюк, Тернопільський національний медичний університет імені І. Я. Горбачевського мОз України, майдан Волі, 1, Тернопіль, 46001, Україна, e-mail: fedonyuklj@tdmu.edu.ua. 